EXTENDED REPORT

\title{
A gene expression signature for recent onset rheumatoid arthritis in peripheral blood mononuclear cells
}

\author{
N J Olsen, T Sokka, C L Seehorn, B Kraft, K Maas, J Moore, T M Aune
}

Ann Rheum Dis 2004;63:1387-1392. doi: 10.1136/ard.2003.017194

See end of article for
authors' affiliations
$\ldots \ldots \ldots \ldots \ldots \ldots \ldots . . . .$.
Correspondence to:
Dr N J Olsen, 5323 Harry
Hines Blvd, Dallas, TX
$75390-8884$, USA;
nancy.olsen@
UTSouthwestern.edu

Accepted 18 January 2004

\begin{abstract}
Background: In previous studies the presence of a distinct gene expression pattern has been shown in peripheral blood cells from patients with autoimmune disease.

Objective: To determine whether other specific signatures might be used to identify subsets of these autoimmune diseases and whether gene expression patterns in early disease might identify pathogenetic factors.

Methods: Peripheral blood mononuclear cells were acquired from patients with rheumatoid arthritis (RA) and analysed by microarrays containing over 4300 named human genes. Patients with RA for $<2$ years were compared with subjects with longstanding RA (average duration 10 years) and with patients with other immune or autoimmune diagnoses.

Results: Cluster analyses permitted separation of the patients with early RA (ERA) from those with longstanding disease. Comparison with other patient groups suggested that the ERA signature showed some overlap with that seen in the normal immune response to viral antigen as well as with a subset of patients with systemic lupus erythematosus.

Conclusions: The ERA signature may reflect, in part, a response to an unknown infectious agent. Furthermore, shared features with some lupus patients suggest that common aetiological factors and pathogenetic pathways may be involved in these two autoimmune disorders.
\end{abstract}

W e and others have shown that patterns of gene expression by peripheral blood mononuclear cells (PBMCs) identify signatures in patients with autoimmune diseases, including rheumatoid arthritis (RA), systemic lupus erythematosus (SLE), multiple sclerosis, and type I diabetes mellitus. ${ }^{1-5}$ In our previous report, the autoimmune signature was shown to be distinct from the normal immune response to vaccination. ${ }^{1}$ In view of these findings, we hypothesised that other groups of genes might be identified that would be specific for disease subsets. We were especially interested in the possibility of identifying a gene expression pattern specific for patients in the early stages of RA because there is a great clinical need for identification of these subjects to facilitate starting definitive treatment. Furthermore, patients in earlier stages of disease are more likely to reflect inciting or aetiological factors of the disorder. As in previous studies, we approached this problem by examining samples of peripheral blood rather than a target tissue like synovium, because screening could be carried out on any subject, not just those who already had joint abnormalities, making it feasible to identify patients with early disease.

For these studies patients with RA with early disease were defined as those who had a diagnosis for $<2$ years and this group was compared with a group of patients with RA with an average disease duration of 10 years. Clustering algorithms permitted separation of these two groups of patients with RA based on the PBMC gene expression data. There was some overlap with genes that are altered in normal subjects in response to a viral antigen, which suggests that some immune abnormalities at this relatively early stage of RA may represent a response to an as yet undetermined infectious agent. The gene expression pattern for RA was also shared, in part, by a subgroup of patients with SLE, suggesting the possibility of overlapping aetiological pathways in these clinically distinct autoimmune disorders.

\section{PATIENTS AND METHODS \\ Patients}

Patients with RA were from clinics at Vanderbilt University and from a private rheumatology practice. All patients satisfied diagnostic criteria for RA. ${ }^{6}$ Disease duration, drugs, and demographic variables were determined from a chart review (table 1). Clinical profiles of the two groups of patients with RA indicated that they differed significantly only in the duration of disease $(p=0.0039$; table 1$)$. The use of prednisone was about twice as high in the group with early RA (ERA) as in the RA group $(p=0.09)$. Use of methotrexate and other disease modifying drugs was not significantly different between the groups. Additional blood samples were collected from 14 patients with SLE, all of whom satisfied American College of Rheumatology criteria for this disease. ${ }^{7}$ None of the patients with SLE had been diagnosed for $<2$ years and their average disease duration was 12.5 years. Blood samples were also obtained from 11 subjects with a clinical diagnosis of allergic disease or asthma. Data from nine control subjects studied before and after influenza vaccination were also analysed; these subjects have been described previously. ${ }^{1}$ These studies were approved by the Vanderbilt University Institutional Review Board.

\section{Sample preparation}

PBMCs were isolated from $20 \mathrm{ml}$ of heparinised blood on Ficoll gradients. Phenotypic profiles of cells separated by this method have been described previously. ${ }^{1}$ Total RNA was isolated with Tri-Reagent (Molecular Research Center, Cincinnati, $\mathrm{OH})$, reverse transcribed with $\left[{ }^{33} \mathrm{P}\right] \mathrm{dCTP}$ and hybridised to Human "Named Genes" GeneFilters microarrays release 1, containing 4329 clones (Research Genetics/Invitrogen

Abbreviations: ERA, early rheumatoid arthritis; $M H C$, major histocompatibility complex; PBMC, peripheral blood mononuclear cell; PCR, polymerase chain reaction; RA, rheumatoid arthritis; SLE, systemic lupus erythematosus; TGF $\beta$, transforming growth factor $\beta$ 
Table 1 Clinical features of patients with early or established RA

\begin{tabular}{llll}
\hline Clinical feature & $\begin{array}{l}\text { Early RA } \\
(\mathbf{n}=11)\end{array}$ & $\begin{array}{l}\text { Established RA } \\
(\mathbf{n}=8)\end{array}$ & p Value† \\
\hline Sex (\% female) & 82 & 100 & 0.15 \\
Age (years)* & $54(4)$ & $60(5)$ & 0.38 \\
White (\%) & 91 & 100 & 0.86 \\
Duration (years)* & $1.1(0.3)$ & $10.5(2.6)$ & 0.001 \\
DMARD use (\%) & 91 & 100 & 0.93 \\
Prednisone use (\%) & 45 & 25 & 0.19 \\
MTX weekly dose (mg) & $10(1)$ & $16(3)$ & 0.12 \\
\hline
\end{tabular}

*Values represent mean (SEM); $\uparrow p$ values calculated by $\chi^{2}$ or Student's $t$ test.

Corporation, Carlsbad, CA). Filters were exposed for 24 hours and then scanned with a phosphorimager (Molecular Dynamics/Amersham Biosciences, Piscataway NJ). The data were normalised so that the average intensity for each clone was equal to 1 . The high reproducibility of the hybridisation method has been described previously. ${ }^{1}$

\section{Real time PCR}

Confirmatory testing was done by real time polymerase chain reaction (PCR) using a spectrofluorimetric thermal cycler (ABI PRISM 7700; Applied Biosystems, Foster City, CA). Each $50 \mu \mathrm{l}$ reaction mixture contained $1 \mu \mathrm{l}$ cDNA and $2 \mathrm{X}$ SYBR-Green PCR master mix buffer. Primers were used at $200 \mathrm{nmol}$ and primer sequences were as follows: for CHI3Ll F: GCC GGA CTT TCA TCA AGT CAG T, R: CAA GGT CCA GCC CAT CAA A; for CHESI F: CCC CGA GAG CGA TGA TGA, R: GAC CGG ATC CCT GCT AAG TG; for JUND F: TCA CAG TTC CTC TAC CCC AAG GT, R: TAA ATC CTC CAG GGC CTT GA. The gene array data indicated that ERA and RA samples had equal levels of expression of JUND, whereas other conventional control genes, including glyceraldehyde3-phosphate dehydrogenase and $\beta$ actin, were differentially expressed. Therefore the genes of interest were compared
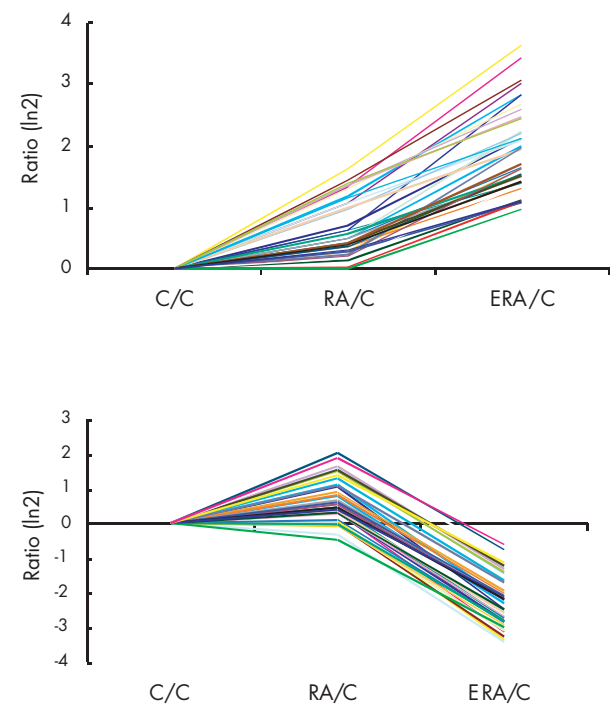

Figure 1 Relative levels of expression of genes in PBMCs from 8 patients with RA, 11 patients with ERA, and 9 normal control subjects (C). Genes that did not vary for any of the conditions (3 SD) were removed from the analyses. Data are shown as the ratio, In 2, for each group compared with controls. Individual lines show expression levels of individual genes.
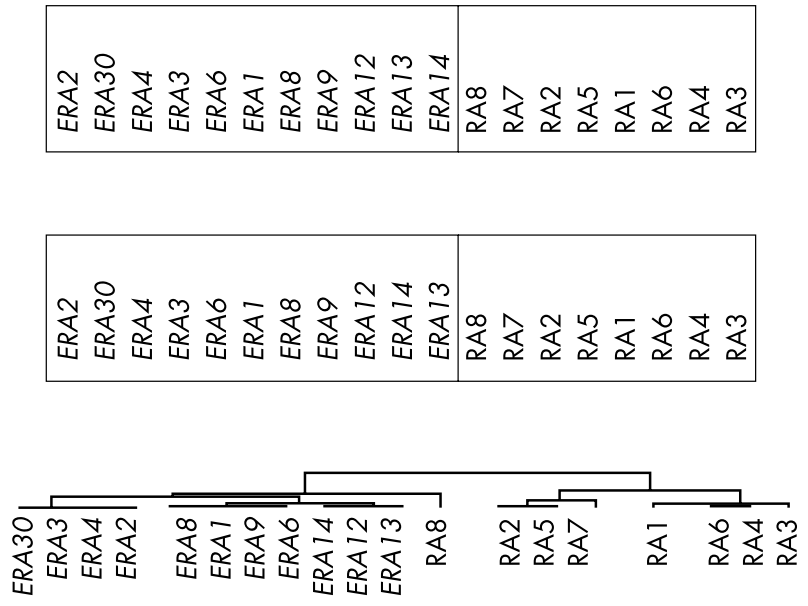

Figure 2 Clustering of patients with ERA and established RA using the self organising map algorithm with two different input vectors (top) and the hierarchical clustering algorithm with complete linkage clustering (bottom). Gene expression data were filtered to include only those that displayed at least three standard deviations of variability.

with JUND as a control. In each case, the threshold cycle number was determined as the mean of three replicates.

\section{Data analysis}

Gene expression data were analysed by the Cluster and Treeview software programs of Eisen (Stanford University, Palo Alto, CA). ${ }^{8}$ The gene expression data were filtered to include only genes that showed significant variability (3 SD) in the clustering analyses. Two different clustering algorithms were applied: self organising maps and hierarchical. ${ }^{9}$ The Research Genetics Pathways 3.0 program was used to identify genes that were different among patients with ERA and RA or controls. The Pathways program expresses results as the ratio of the natural logarithm (ln); other analyses were done using $\log _{2}$. Clinical variables and gene expression data in the two RA groups were compared using an unpaired Student's $t$ test or a $\chi^{2}$ test for discontinuous variables. Values of $\mathrm{p}<0.05$ were considered significant.

\section{RESULTS}

Gene expression levels in both RA groups were compared with those of normal control subjects after filtering out genes that did not show at least three standard deviations of variability for any of the conditions (fig 1). Using this approach, we identified two sets of genes that were similar for patients with established RA and normal control subjects but whose expression was either up regulated or down regulated in the patients with ERA. This finding suggested the existence of unique gene expression patterns in ERA.

Further analyses were performed using clustering algorithms. The gene expression values were filtered and the self organising map algorithm was applied using two different sets of input vectors (fig 2, top). The SOM clustering was repeated 10 times and the only variability noted was the occasional appearance of patient RA8 inside one end of the ERA cluster. The hierarchical clustering algorithm was also applied to the same dataset (fig 2, bottom). Patients with ERA were again separated from the patients with RA. In this approach patient RA8 appears on a stem that is somewhat separated from the ERA group. Thus, these two clustering algorithms, which have distinctly different mathematical approaches ${ }^{9}$ yielded essentially the same results.

The ERA and RA groups showed some difference in the usage of prednisone $(\mathrm{p}=0.19$; table 1$)$. To investigate the possibility that this might affect the observed differences, 
Table 2 Genes up regulated more than threefold in early RA

\begin{tabular}{llll}
\hline Category & Gene identifier & $\begin{array}{l}\text { Chromosome } \\
\text { location }\end{array}$ & Description \\
\hline Immune/growth factor & CSTF2 & Xq22.1 & Cleavage stimulation factor \\
& CSF3R & $1 p 34.3-35$ & $\begin{array}{l}\text { CSF 3 receptor (granulocyte) } \\
\text { TGF } \beta \text { receptor II }\end{array}$ \\
& TGFBR2 & $3 p 24.1$ & \\
Metabolism & CYP3A4 & $7 q 22.1$ & $\begin{array}{l}\text { Cytochrome P450 subfamily IIIA } \\
\text { 11 } \beta \text {-Hydroxysteroid dehydrogenase 2 }\end{array}$ \\
Neuromuscular & HSD11B2 & $16 q 22$ & Syntropin $\alpha$, neuromuscular junction protein \\
& SNTA1 & $20 q 11.2$ & Troponin I, skeletal, fast twitch \\
& TNNI2 & $11 p 15.5$ & Troponin T2, cardiac \\
Transcription & TNNT2 & $1 \mathrm{q} 32$ & Zinc finger protein 74 (Cos52) \\
\hline
\end{tabular}

the gene expression data were reanalysed by grouping the patients with RA according to prednisone use rather than by disease duration. One group $(n=12)$ consisted of patients who were not taking prednisone and the second group $(n=7)$ included all patients who were taking prednisone (average daily dose $9 \mathrm{mg}$ ). Mean gene expression values were compared in the two groups by $t$ test. Only one gene (ENCl) was differentially expressed by at least threefold, and the difference was not significant $(p=0.5)$; six genes showed at least a twofold difference, and none of these differences were significant $(p>0.2)$. This result contrasts with the highly significant differences in many genes that were seen in groups defined by disease duration $\left(\mathrm{p}<10^{-3}\right)$ and suggests that prednisone treatment does not explain the findings.

We next sought to identify the genes that showed significant differences between the groups with early and established RA by comparing mean gene expression values. Genes that showed greater than a threefold difference in

Table 3 Genes down regulated more than threefold in early RA

\begin{tabular}{|c|c|c|c|}
\hline Category & Gene identifier & $\begin{array}{l}\text { Chromosome } \\
\text { location }\end{array}$ & Description \\
\hline Immune/inflammatory & $\begin{array}{l}\text { CCR1 } \\
\text { PTGES } \\
\text { LMAN1 } \\
\text { NSEP1 } \\
\text { FKPB 1A } \\
\text { IFI30 } \\
\text { HLA-DP1A } \\
\text { B2M } \\
\text { FYB } \\
\text { HLA-DR4A }\end{array}$ & $\begin{array}{l}3 p 21.31 \\
9 q 34.11 \\
18 q 21.3-22 \\
1 p 34 \\
20 p 13 \\
19 p 13.1 \\
6 p 21.3 \\
15 q 21-22.2 \\
5 p 14.1 \\
6 p 21.3\end{array}$ & $\begin{array}{l}\text { Chemokine receptor (c-c motif) } \\
\text { Prostaglandin E synthase } \\
\text { Mannose binding lectin I } \\
\text { Nuclease sensitive element binding protein } \\
\text { FK506 binding protein IA } \\
\text { IFN } \gamma \text { inducible protein } 30 \\
\text { MHC class II DP } \alpha \text { I } \\
\beta_{2}-\text { Microglobulin; MHC class I } \\
\text { FYN binding protein; T cell signalling } \\
\text { MHC class II DR } \alpha\end{array}$ \\
\hline \multirow[t]{9}{*}{ Cancer/neoplasia } & SAT & Xp22.1 & $\begin{array}{l}\text { Spermidine/spermine N1-acetyltransferase; } \\
\text { carcinogenesis }\end{array}$ \\
\hline & RAB7 & $3 q 22.1$ & RAS oncogene family \\
\hline & SSX3 & Xp11.2-11.1 & Synovial sarcoma breakpoint 3 \\
\hline & LAMR1 & $3 p 21.3$ & Laminin receptor expressed in colon carcinome \\
\hline & M17S2 & $17 q 21.31$ & Ovarian carcinoma antigen (CA-125) \\
\hline & PTPRA & $20 p 13$ & $\begin{array}{l}\text { Protein tyrosine phosphatase; neoplastic } \\
\text { transformation }\end{array}$ \\
\hline & SAS & $12 q 13-14$ & Sarcoma amplified sequence \\
\hline & LCPI & $19 p 13.3$ & L-Plastin; related to colon cancer metastasis \\
\hline & $\begin{array}{l}\text { LRP8 } \\
\text { S100A10 }\end{array}$ & $\begin{array}{l}17 q 11-21.3 \\
1 q 21\end{array}$ & $\begin{array}{l}\text { LIM and SHE protein-1 (LASP-1) } \\
\text { S100 calcium binding protein }\end{array}$ \\
\hline $\begin{array}{l}\text { Transcription/translation/ } \\
\text { cell cycle }\end{array}$ & $\begin{array}{l}\text { CAP } \\
\text { ARPC5 } \\
\text { ARHGDIB } \\
\text { ARPC3 } \\
\text { HIFIA } \\
\text { CHES1 }\end{array}$ & $\begin{array}{l}1 p 34.2 \\
1 q 25.3 \\
12 q 12.3 \\
12 q 24 \\
14 q 21-24 \\
14 q 32.11\end{array}$ & $\begin{array}{l}\text { Adenylyl cyclase associated protein } \\
\text { Actin related protein subunit } 5 \\
\text { Rho GDP dissociation inhibitor } \\
\text { Actin related protein subunit } 3 \\
\text { Hypoxia inducible factor } \\
\text { Checkpoint suppressor } 1\end{array}$ \\
\hline Growth factors & $\begin{array}{l}\text { SNX2 } \\
\text { ZFP364 } \\
\text { LTBP1 }\end{array}$ & $\begin{array}{l}5 q 23 \\
14 q 22-24 \\
2 p 21-22\end{array}$ & $\begin{array}{l}\text { Sorting nexin 2; EGF receptor pathway } \\
\text { EGF response factor } 1 \\
\text { Latent TGF } \beta \text { binding protein } 1\end{array}$ \\
\hline Metabolism & $\begin{array}{l}\text { OAZ1 } \\
\text { CYP24 } \\
\text { POR } \\
\text { METTL1 }\end{array}$ & $\begin{array}{l}2 p 25 \\
20 q 13.2-13.3 \\
7 q 11.23 \\
12 q 13\end{array}$ & $\begin{array}{l}\text { Ornithine decarboxylase antizyme } 1 \\
\text { Cytochrome P450 subfamily } 24 \\
\text { P450 cytochrome oxidoreductase } \\
\text { Methyltransferase-like } 1\end{array}$ \\
\hline Cartilage/bone & $\begin{array}{l}\text { CHI3L1 } \\
\text { BMP4 }\end{array}$ & $\begin{array}{l}1 q 31.1 \\
14 q 22-23\end{array}$ & $\begin{array}{l}\text { Chitinase 3-like (cartilage glycoprotein-39) } \\
\text { Bone morphogenetic protein } 4\end{array}$ \\
\hline
\end{tabular}



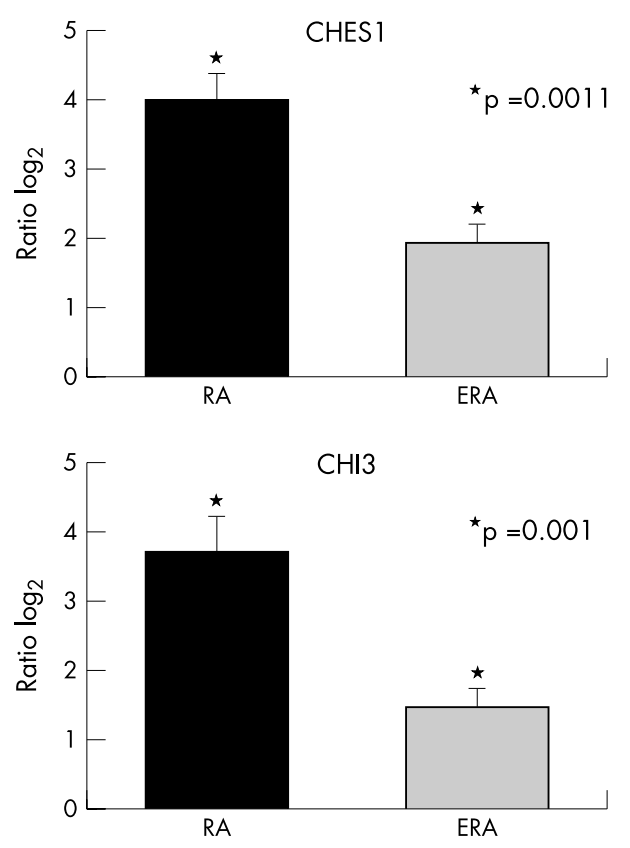

Figure 3 Real time PCR confirmation of differential expression for the genes $\mathrm{CHI} 3$ and $\mathrm{CHES1}$, both of which are up regulated on the gene arrays by eightfold or greater in RA compared with ERA. Values represent means from 5 subjects with RA and 11 with ERA. Normalisation to corresponding values for JUND were carried out for each subject. Relative increases are indicated as $\log _{2}$.

their expression level, with a high level of significance $(\mathrm{p}<0.0005)$ between the two groups are shown (tables 2 and $3)$. Nine genes were up regulated in ERA compared with established RA (table 2), including three with immune system activities, TGF $\beta$ receptor II, CSF3 receptor, and cleavage stimulation factor, ${ }^{10}$ and two that influence levels or activity of glucocorticoids, cytochrome P450 subfamily IIIA and 11- $\beta$ hydroxysteroid dehydrogenase 2 .

The second group of genes included 44 that were down regulated by more than threefold in ERA compared with established RA. Some of these genes could be grouped into functional categories (table 3). The two largest categories, with 10 genes each, encode proteins that have known immune and inflammatory functions or are linked to cell proliferation and neoplasia. The first of these groups included three major histocompatibility complex (MHC) proteins, the class I molecule $\beta_{2}$-microglobulin, and two class II molecules, $\mathrm{DP} \alpha \mathrm{l}$ and $\mathrm{DR} \alpha$, as well as an interferon $\gamma$ inducible protein (IFN $\gamma$ inducible protein 30) involved in MHC restricted processing of antigen ${ }^{11}$ and nuclease sensitive element binding protein 1 , a negative regulator of MHC class II genes. ${ }^{12}$ One gene, mannose binding lectin 1 , is part of the innate immune response system and serum levels of this protein may be correlated with later joint damage in patients with early synovitis. ${ }^{13}$ Ten genes in the second category were associated with cancer, either as tumour markers or as proteins involved in processes of proliferation, differentiation or transformation (table 3 ).

A group of six genes encoded proteins involved in cellular proliferation or cell cycle progression, including transcription factors. Three genes were in the epidermal growth factor or transforming growth factor $\beta$ (TGF $\beta$ ) pathways that have activities in both neoplasia and in the immune system. ${ }^{12}{ }^{14-16}$ Two proteins were in the cartilage and bone group. The first, bone morphogenetic protein 4 , is a member of the TGF $\beta$ superfamily, so it also belongs to the growth factor group. ${ }^{17}$ This pluripotent molecule is involved in immune regulation and in neoplastic or metastatic processes as well as in bone remodelling. ${ }^{17}$ The second, cartilage glycoprotein-39 (or YKL-4), is a joint derived autoantigen that is increased in inflamed joints and serum of patients with active RA. ${ }^{18}$

Other down regulated genes include three involved in actin polymerisation, two translation factors, and two Golgi proteins, all consistent with a general state of cellular activation and proliferation.

The genes that were down regulated in ERA showed clusters on three separate chromosomes (table 3). Chromosome 1 included two clusters with a total of five genes, and chromosomes 12 and 14 each included one cluster of four genes. Although susceptibility candidate genes for RA have been located on chromosomes 1 and $12,{ }^{19}$ no candidates have been identified on chromosome 14. Two dysregulated genes, both MHC class II proteins, were located on chromosome 6, which has been identified as having the strongest genetic contribution to RA susceptibility.

We were interested in further examining the ERA signature to see if it overlapped with the normal immune response. For this analysis, we used data from previously studied normal subjects who had received influenza vaccination. ${ }^{1}$ Of the 4133 array genes, $106(2.6 \%)$ were up regulated in ERA by at least twofold and $400(9.7 \%)$ were up regulated in the vaccine response. A total of 26 genes were up regulated in both responses. The predicted overlap if these two responses were independent, would be only 10 genes $((2.6 \% \times 9.7 \%)$ of 4133$)$. A comparison of the observed overlap $(26 / 4133)$ and the expected overlap (10/4133) shows a significant difference $\left(\chi^{2}=7.4 ; \mathrm{p}=0.0075\right)$. This result suggests that the ERA signature might share features with the normal response to an infectious agent.

Two named genes showed differences between RA and ERA of eightfold or greater. Both of these genes, CHI3Ll (chitinase 3-like 1; cartilage glycoprotein-39) and CHES 1 (checkpoint suppressor 1), were overexpressed in the RA group. Real time PCR analysis for these genes was carried out and levels were normalised to the proto-oncogene JUND (fig 3). Both CHI3 and CHESI were significantly higher in RA than in ERA ( $p=0.001$ for CHI3 and $p=0.0011$ for CHES 1 ), confirming the array results.

Genes responsible for differences between patients with early and established RA were then examined further to determine whether expression levels could be used to classify the patients with RA as having early or established disease. We first confirmed that both groups of patients with RA fit our previously described equation found in autoimmune subjects and unaffected first degree relatives. ${ }^{1}$ For both RA groups, each patient had a score of 0 in this 35 gene equation, confirming that the autoimmune signature was uniformly conserved in early RA.

To look for equations specific for ERA, mean expression levels for each gene were compared for eight subjects in each group ERA and RA, and a ratio (ERA/RA) was calculated for each gene. These ratios were sorted to disclose a sets of eight genes that were significantly up regulated by at least threefold in ERA compared with RA. Inspection of the gene expression levels for subjects in each group confirms the differences (fig 4). A score was then derived using a value of 1 for gene expression levels that were above the overall mean and a value of 0 for those below the mean. This approach is similar to that used to derive our equation for autoimmune disease $^{1}$ and is based on the principle of linear discriminant analysis. ${ }^{20}$ The mean (SEM) score derived from these eight genes was $0.13(0.13)$ in the RA group and $7.88(0.13)$ in the ERA group, a difference that was highly significant $\left(p=2.17 \times 10^{-16}\right)($ fig 5$)$. This equation was then tested with nine additional patients with ERA who had not been included in the original gene equation calculations. The 


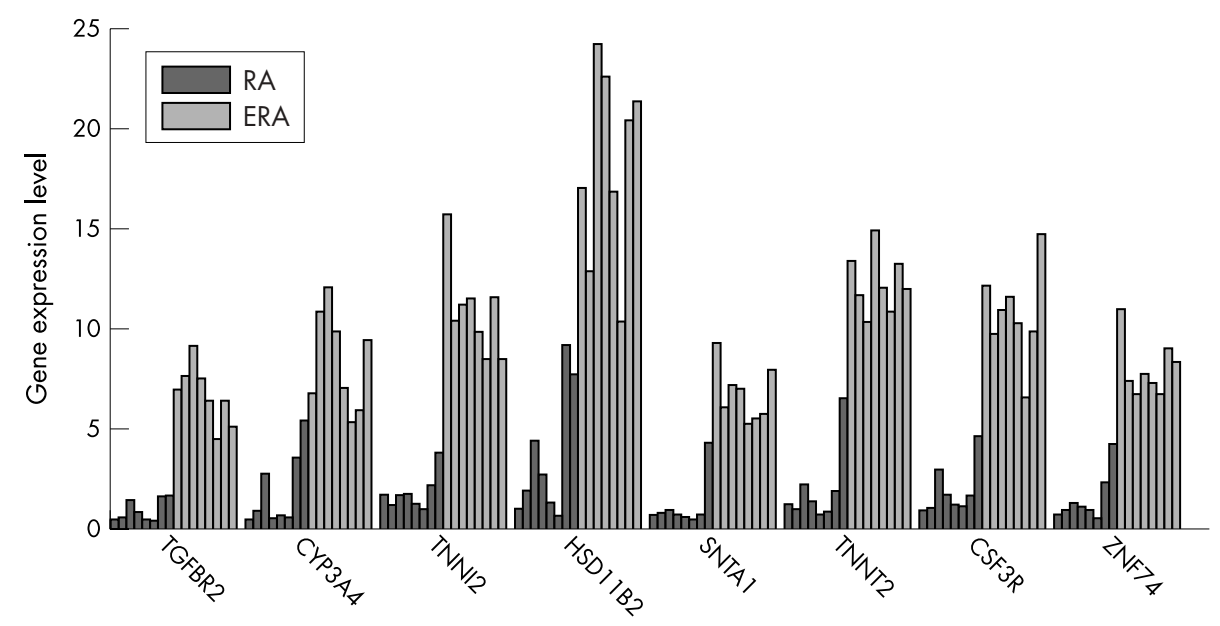

Figure 4 Gene expression levels for eight genes significantly up regulated in ERA. Results from individual patients are shown for eight patients with established RA (dark grey bars) and eight patients with ERA (light grey bars).

mean score for this group (ERA2) was 7.11 (0.31), which was also significantly different from the established RA group $\left(\mathrm{p}=1.39 \times 10^{-11}\right)$. The equation was also tested in 14 patients with SLE. These subjects showed two subsets, one with values of 7-8 and other with values of 0 or 1 . Inspection of the clinical records of these subjects indicated that $30 \%$ of the patients with SLE with high scores had a history of renal disease compared with $62 \%$ of those with low scores. However, this difference was not significant $(p=0.17)$. Furthermore, these two groups of patients with SLE had similar disease duration (approximately 11 years; $p=0.97$ ), and none of the patients with SLE studied had disease duration of $<2$ years. Patients with allergic disease and normal control subjects did not express the ERA signature.

\section{DISCUSSION}

Results of this study suggest that an early stage of RA is associated with a distinct gene expression profile in PBMCs. This gene pattern might be considered a marker for ERA and may reflect aetiological or pathogenetic factors. The possibility that the ERA signature reflects, in part, an immune response to an unidentified infectious agent is suggested by some of the analyses here; further study of this association

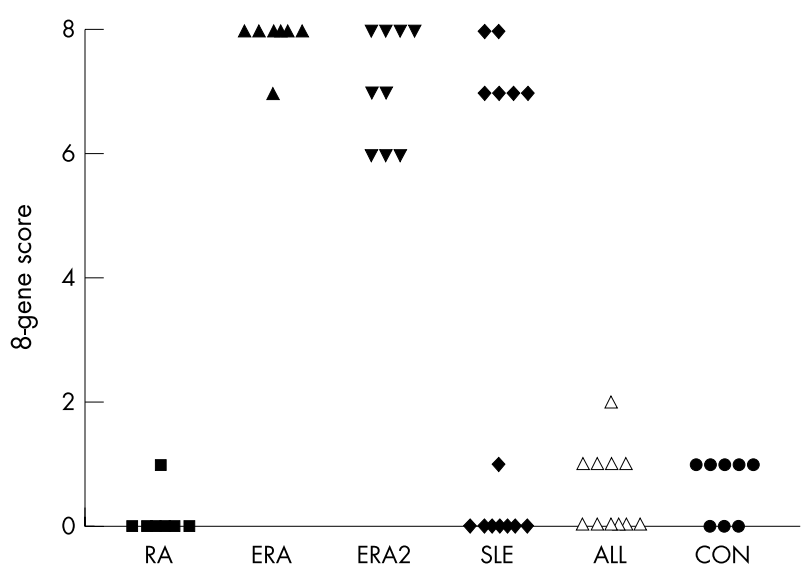

Figure 5 Score derived from eight genes that distinguish ERA from RA. The eight genes that were up regulated in ERA used to generate the equation were: TGFBR2, CYP3A4, TNNI2, HSD1 1B2, SNTA1, TNNT2, CSF3R, ZNF74. The ERA and RA groups with eight subjects each were used to generate the score. The equation was retested in a second group of patients with ERA (ERA2) who were not used to derive the score and in patients with SLE, and allergic disease (ALL) as well as in normal control subjects (CON). would be of interest. The gene expression signature does not appear to be related to treatment with prednisone, as there were no significant differences when patients were sorted according to use of this drug. However, whether this profile is correlated with measures of disease activity has not been established. Discrimination between the effects of disease and drugs on the gene expression profile could be determined in longitudinal studies. We plan to follow up the patients with ERA who are being enrolled in a long term outcome study to determine correlates of the ERA signature and the loss of this signature over time.

We have previously reported that patients with autoimmune disease share a common gene expression signature that is independent of the clinical diagnosis. ${ }^{1}$ The present study demonstrates that other sets of genes can be used to distinguish between subsets of autoimmune patients. However, the ERA equation was not unique, because a subset of patients with SLE shared the ERA signature. These patients with SLE did not have early disease, and other potential explanations for the separation into two groups are not immediately apparent. This finding reinforces our previous view that distinct autoimmune syndromes share many similarities, and RA and SLE appear to be especially difficult to separate completely. Further studies in a larger, well characterised SLE population are planned to probe the basis for the SLE subsets.

The gene expression pattern offers a possible approach to early diagnosis of RA. Although new treatments for RA have greatly improved outcomes in this disease, early and accurate diagnosis remains of primary importance to avoid long term disability. ${ }^{21}$ However, it is currently not easy to identify these patients, in part because the nature of the initial insult remains unidentified. Patients who seek medical attention for treatment of undifferentiated synovitis may include some with RA as well as others who have syndromes that would require different forms of treatment. ${ }^{22}{ }^{23}$ Recently developed tests based on the presence of antibodies to cyclic citrullinated peptide have been advocated as a way to find early, patients at risk for development of significant disease. Although anti-cyclic citrullinated peptide antibodies are very specific for RA, sensitivity may be $<70 \% .{ }^{24}$ Furthermore, it may be most prognostic for patients with mild disease. ${ }^{25}$ Rheumatoid factor and DRBI*04 genes correlate with erosive disease, but are not necessarily predictive in the individual patient. ${ }^{26}{ }^{27}$ Non-invasive approaches using magnetic resonance imaging or ultrasound are sensitive to the presence of early synovitis, ${ }^{28}{ }^{29}$ but are not useful screening tools owing to their expense and limited availability. Furthermore, because synovitis may precede clinical symptoms, with changes 
appearing as early as 2 months, even these approaches may miss patients with potentially destructive abnormalities. ${ }^{30}$

Our patients with ERA had all been referred to a rheumatologist for evaluation, a process that in the United States probably takes more than 3-6 months, and the patients with ERA in this study in fact had a history of symptoms for an average of 1 year before diagnosis. Whether this same approach and the equations generated (fig 5) or combinations of other genes could identify subjects with undifferentiated synovitis or early stages of other autoimmune disorders like lupus or multiple sclerosis is under active investigation.

In addition to disease categorisation, analysis of gene expression in peripheral blood offers the possibility of discovering new pathogenic pathways or molecules. In ERA, gene expression patterns may reflect responses to factors that have triggered the autoimmune response in a susceptible host. The genes that showed differential regulation in these patients include several that might be viewed as candidate genes-namely, three, CSTF2, CSF3R, and TGFBR2, which affect the function of B cells. Pathogenic autoantibodies are probably produced very early in the course of RA, and may reflect changes in B lymphocytes. ${ }^{31}$ Emerging techniques that permit study of small tissue samples from the synovium will be of interest to see if some of these same genes or pathways are also dysregulated in the targeted joint. ${ }^{32}$

\section{ACKNOWLEDGEMENTS}

We appreciate the technical assistance of Annette Oeser, Robert Yelverton, and Xuan Li and support from Dr C Michael Stein. Special thanks are extended to Drs Joseph Huston, Howard Fuchs, Theodore Pincus, S Bobo Tanner, and the other Vanderbilt physicians who allowed us to study their patients.

Support was from NIH (AI44924, AR41943, DK58765, AI053984, HL 67964), a Vanderbilt University Medical Center Discovery Grant and the Morgan Family Foundation. B Kraft was supported, in part, by NIH training grant HL69765.

\section{Authors' affiliations}

N Olsen, T Sokka, C L Seehorn, B Kraft, T Aune, Department of Medicine, Division of Rheumatology and Immunology, Vanderbilt University, Nashville TN 37232, USA

N Olsen, T M Aune, B Kraft, Department of Microbiology and Immunology, Vanderbilt University, Nashville TN 37232, USA J Moore, Program in Human Genetics and Department of Molecular Physiology and Biophysics, Vanderbilt University, Nashville TN 37232, USA

T Sokka, Jyväskylä Central Hospital, Jyväskylä, Finland

\section{REFERENCES}

1 Maas K, Chan S, Parker J, Slater A, Moore J, Olsen N, et al. Cutting edge: molecular portrait of human autoimmune disease. J Immunol 2002;169:5-9.

2 Bennett L, Palucka AK, Arce E, Cantrell V, Borvak J, Banchereau J, et al. Interferon and granulopoiesis signatures in systemic lupus erythematosus blood. J Exp Med 2003;197:711-23.

3 Bomprezzi R, Ringner M, Kim S, Bittner ML, Khan J, Chen Y, et al. Gene expression profile in multiple sclerosis patients and healthy controls: identifying pathways relevant to disease. Hum Mol Genet 2003;12:2191-9.

4 Han GM, Chen SL, Shen N, Ye S, Bao CD, Gu YY. Analysis of gene expression profiles in human systemic lupus erythematosus using oligonucleotide microarray. Genes Immun 2003;4:177-86.

5 Jarvis JN, Frank MB, Dozmorov I, Jiang K, Cadwell C, McGhee JL, et al. Gene expression analysis of children with active polyarticular JRA [abstract]. Arthritis Rheum 2002;46(suppl):S474.
6 Arnett FC, Edworthy SM, Bloch DA, McShane DJ, Fries JF, Cooper NS, et al. The American Rheumatism Association 1987 revised criteria for the classification of rheumatoid arthritis. Arthritis Rheum 1988;31:315-24.

7 Tan EM, Cohen AS, Fries JF, Masi AT, McShane DJ, Rothfield NF, et al. The 1982 revised criteria for the classification of systemic lupus erythematosus. Arthritis Rheum 1982;25:1271-7.

8 Eisen MB, Spellman PT, Brown PO, Botstein D. Cluster analysis and display of genome-wide expression patterns. Proc Natl Acad Sci USA 1998;95:14863-8.

9 Sherlock G. Analysis of large-scale gene expression data. Curr Opin Immunol 2000;12:201-5.

10 Takagaki Y, Manley JL. Levels of polyadenylation factor CstF-64 control IgM heavy chain mRNA accumulation and other events associated with $B$ cell differentiation. Mol Cell 1998;2:761-71.

11 Arunachalam B, Phan UT, Geuze HJ, Cresswell P. Enzymatic reduction of disulfide bonds in lysosomes: characterization of a gamma-interferoninducible lysosomal thiol reductase (GILT). Proc Nat Acad Sci USA 2000;97:745-50

12 Didier DK, Schiffenbauer J, Woulfe SL, Zacheis M, Schwartz BD. Characterization of the CDNA encoding a protein binding to the major histocompatibility complex class II Y box. Proc Natl Acad Sci USA 1988:85:7322-6.

13 Saevarsdottir S, Vikingsdottir T, Vikingsson A, Manfredsdottir V, Geirsson AJ, Valdimarsson $\mathrm{H}$. Low mannose binding lectin predicts poor prognosis in patients with early rheumatoid arthritis. A prospective study. J Rheumatol 2001;28:728-34.

14 Leveen P, Larsson J, Ehinger M, Cilio CM, Sundler M, Sjostrand $\sqcup$, et al. Induced disruption of the transforming growth factor beta type II receptor gene in mice causes a lethal inflammatory disorder that is transplantable. Blood 2002; 100:560-8.

15 Mendelsohn J, Baselga J. The EGF receptor family as targets for cancer therapy. Oncogene 2000;19:6550-65.

16 Davies DE, Polosa R, Puddicombe SM, Richter A, Holgate ST. The epidermal growth factor receptor and its ligand family: their potential role in repair and remodelling in asthma. Allergy 1999;54:771-83.

17 Leong LM, Brickell PM. Bone morphogenic protein-4. Int J Biochem Cell Biol 1996;28:1293-6.

18 Baeten D, Boots AM, Steenbakkers PG, Elewaut D, Bos E, Verheijden GF, et al. Human cartilage gp-39+, CDI6+monocytes in peripheral blood and synovium: correlation with joint destruction in rheumatoid arthritis. Arthritis Rheum 2000;43:1233-43

19 Jawaheer D, Seldin MF, Amos Cl, Chen WV, Shigeta R, Monteiro J, et al. A genomewide screen in multiplex rheumatoid arthritis families suggests genetic overlap with other autoimmune diseases. Am J Hum Genet 2001;68:927-36.

20 Fisher RA. The use of multiple measurements in taxonomic problems. Ann Eugen 1936;7:188.

21 March L, Lapsley $\mathrm{H}$. What are the costs to society and the potential benefits from the effective management of early rheumatoid arthritis? Best Pract Res Clin Rheumatol 2001;15:171-85.

22 Courtney PA, Wright GD. Referrals to an "early synovitis clinic": are they appropriate? Ann Rheum Dis 2001;60:991-2.

23 Gormley G, Steele K, Gilliland D, Stevenson M, O'Reilly D, McKane R, et al. Can rheumatologists agree on a diagnosis of inflammatory arthritis in an early synovitis clinic? Ann Rheum Dis 2001;60:638-9.

24 Lee DM, Schur PH. Clinical utility of the anti-CCP assay in patients with rheumatic diseases. Ann Rheum Dis 2003;62:870-4.

25 Jansen LM, van Schaardenburg D, van der Horst-Bruinsma I, van der Stadt RJ, de Koning MH, Dijkmans BA. The predictive value of anti-cyclic citrullinated peptide antibodies in early arthritis. J Rheumatol 2003;30:1691-5.

26 Bukhari M, Lunt M, Harrison BJ, Scott DG, Symmons DP, Silman AJ. Rheumatoid factor is the major predictor of increasing severity of radiographic erosions in rheumatoid arthritis: results from the Norfolk Arthritis Register Study, a large inception cohort. Arthritis Rheum 2002;46:906-12.

27 Combe B, Dougados M, Goupille P, Cantagrel A, Eliaou JF, Sibilia J, et al. Prognostic factors for radiographic damage in early rheumatoid arthritis: a multiparameter prospective study. Arthritis Rheum 2001;44:1736-43.

28 Roben P, Barkmann R, Ullrich S, Gause A, Heller M, Gluer CC. Assessment of phalangeal bone loss in patients with rheumatoid arthritis by quantitative ultrasound. Ann Rheum Dis 2001;60:670-7.

29 Sugimoto H, Takeda A, Hyodoh K. MR imaging for evaluation of early rheumatoid arthritis. Semin Musculoskelet Radiol 2001;5:159-65.

30 Tak PP. Is early rheumatoid arthritis the same disease process as late rheumatoid arthritis? Best Pract Res Clin Rheumatol 2001;15:17-26.

31 Halldorsdottir HD, Jonsson T, Thorsteinsson J, Valdimarsson H. A prospective study on the incidence of rheumatoid arthritis among people with persistent increase of rheumatoid factor. Ann Rheum Dis 2000;59:149-51.

32 Boyle DL, Rosengren S, Bugbee W, Kavanaugh A, Firestein GS. Quantitative biomarker analysis of synovial gene expression by real-time PCR. Arthritis Res Ther 2003;5:R352-60. 